\title{
Potensi Daun Teh (Camellia sinensis) dan Daun Anting- anting Acalypha indica $L$. dalam Menghambat Pertumbuhan Salmonella typhi
}

\author{
Nita Noriko ${ }^{1}$ \\ ${ }^{1}$ Program Studi Biologi, Fakultas Sains dan Teknologi, Universitas Al Azhar Indonesia, Kompleks Masjid \\ Agung Al Azhar, Jakarta Selatan, 12110, Indonesia
}

E-mail: nita_noriko@uai.ac.id

\begin{abstract}
Abstrak - Salmonella typhi adalah bakteri penyebab terjadinya penyakit typhus. Pengobatan menggunakan antibiotika menimbulkan resistensi jika dilakukan tidak tuntas terutama ketika sistem tubuh menurun. Pengobatan dengan menerapkan kearifan lokal merupakan salah satu alternatif dalam upaya penyembuhan. Daun teh (Camellia sinensis) dan daun anting-anting (Acalypha indica L) diduga mengandung tanin, suatu senyawa yang dapat berfungsi sebagai antibiotik. Tujuan dari penelitian ini adalah memperoleh informasi efektifitas ekstrak daun teh dan daun antinganting sebagai antibakteri alami, khususnya $S$. typhi Penelitian dilakukan pada bulan Maret hingga Oktober 2012 di Laboratorium Mikrobiologi Universitas Al Azhar Indonesia. Tahapan penelitian terdiri dari pembuatan ekstrak daun teh dan anting-anting, pengujian adanya kandungan tanin, penumbuhan $S$. typhi dan uji antibakteri. Ekstrak daun diperoleh dengan cara perebusan dan pengeringan. Hasil penelitian menunjukkan bahwa ekstrak daun teh dan anting-anting berpotensi untuk dikembangkan sebagai antibiotik. Hal ini ditunjukkan dengan terbentuknya zona bening ketika dilakukan uji antibakteri. Kedua ekstrak daun tersebut positif mengandung tanin yang diduga berperan dalam penghambatan pertumbuhan $S$. typhi.
\end{abstract}

Abstract - Salmonella typhi is a bacteria that caused typhus disease. The curation using chemical drugs may cause bacterial resistance if the treatment is not complete, especially when the system of the body decreases. Treatment with traditional medicine is one of alternative way for curing typhoid fever. Tea and Anting- anting leaves are suspected to contain tannin, a compound that can act as an antibiotic. The aim of the research is getting information about effectiveness of tea and anting-anting leaf extract as antibacterial agent specially $S$. thypi. Research were conducted from Maret until October 2012 in Microbiology Laboratory, Al Azhar Indonesia University. The steps incude collecting tea and anting-anting leaves, extracting tannin, testing for tannin, growing the bacteria, and testing the inhibition zone. Leaf extract obtained by boiling and drying. The research shows that leaf tea and anting-anting extraction have potential to be developed as an antibiotic. That are showed by clear zone as indicate inhibition Salmonella typhi when tested antibacterial. Both of the leaves plant are positive tannin containing, and it is indicated as inhibitor $S$. thypi growth.

Keywords - Salmonella typhi, Camellia sinensis, Acalypha indica L, tanin, antibacteria

\section{PENDAHULUAN}
A ngka penyakit typhus di Asia Asia Selatan dan Tengah termasuk Asia Tenggara terjadi $>100 / 100,000$ penduduk/tahun). Insiden penyakit tersebut di Asia, Afrika, Amerika Latin, Karibia, Australia, New Zealand, Eropa, Amerika Utara (10- 100/100.000 kasus/tahun). Secara global diperkirakan dari 21.650.974 kasus terdapat 216.510 kematian sepanjang tahun 2000 [1].
Pengobatan penyakit typhus yang tidak tuntas akan memberikan efek infeksi sistemik pada organ tubuh lain, dan dapat menyebabkan kematian. Penyakit typus selain menyerang usus juga menyerang 
kantong empedu, limpa, dan hati. Dengan demikian dibutuhkan upaya penanggulangannya [2].

Tanaman teh berpotensi sebagai antibakteria karena mengandung bioaktif di antaranya adalah tanin [3]. Tanaman teh sudah lama dikenal oleh penduduk dunia sebagai bahan minuman maupun sebagai obat herbal yang mudah diperoleh masyarakat. Salah satu bioaktif yang terkandung pada pucuk teh hijau adalah tanin. Selain tanaman teh, masyarakat juga mengenal tanaman Anting-anting (Acalypha indica $L$ ) yang memiliki nama lokal Lelatang atau Rumput Kokosengan sebagai obat-obatan terutama sebagai sebagai antibakteri.

Bahan bioaktif antibakteri yang terdapat pada daun anting-anting kemungkinan adalah tanin. Tanin yang merupakan senyawa fenolik terkandung pada berbagai jenis tumbuhan hijau dengan kadar yang berbeda-beda [4]. Tanin termasuk ke dalam golongan senyawa polifenol. Salah satu manfaat dari tanin adalah sebagai antibakteri. Tanin sebagai antibakteri dapat menghambat sintesis protein bakteri [5].

Berdasarkan informasi tersebut maka daun teh dan daun anting-anting perlu diteliti lebih lanjut untuk dijadikan obat antibakteri. Hal ini mengingat pengobatan menggunakan herbal saat ini menjadi perhatian yang besar di masyarakat. Perhatian ini disebabkan kekhawatiran masyarakat akan efek samping obat kimia dan juga kesulitan dalam memperoleh maupun dalam mengkonsumsi obat terutama pada masyarakat yang berada di daerah terpencil.

\section{TINJAUAN PUSTAKA}

\section{Salmonella typhi}

Salmonella typhi memiliki bentuk seperti batang dengan alat gerak flagel peritrik dan tidak membentuk spora, dengan ukuran 2-4 mikrometer X 0,5-0,8 mikrometer [6]. Infeksi S. thypi ke dalam tubuh dapat memberikan efek sistemik yang disebabkan oleh pengaruh toxin yang virulen. Toxin tersebut dapat diterima oleh reseptor sel yang berbahan dasar glycoprotein [7].

S. typhi dapat masuk ke dalam tubuh melalui makanan yang tercemar. Masuknya bakteri ini sulit untuk dikontrol. Selain itu bakteri ini memiliki kemampuan untuk berubah secara genotif dan fenotif sebagai bentuk respon terhadap perubahan lingkungan. Dengan kemampuannya tersebut, maka tidak dapat dihilangkan dari rantai makanan. $S$. thypi juga memiliki resistensi terhadap pemanasan hingga $60^{\circ} \mathrm{C}$ selama 60 menit. Pada $\mathrm{pH}$ yang rendah masih dapat bertahan karena resistensinya terhadap asam, walaupun dengan tingkat kematian $90 \%$. Bakteri ini juga mampu bertahan di dalam asam lambung. Hal ini disebabkan karena tingginya kandungan lemak pada matriks membrane plasmanya [8].

Adanya resistensi $S$. thypi terhadap antibiotika mendorong penelitian lebih lanjut terutama ke arah genetika. Hasil penelitian menunjukkan adanya faktor virulen yang diekspresikan ketika bakteri ini menginfeksi host dan mengkode pembentukan peptide antimikroba. Gen tersebut diekspresikan pada apparatus flagel, kemotaksis dan sistem transport Fe secara in vivo [9].

\section{Tanin}

Tanin merupakan senyawa yang dapat dilarutkan oleh gliserol, air, hidroalkohol dan alkohol. Akan tetapi, tanin tidak dapat larut dalam petroleum, benzen dan eter. Tanin dapat terdegradasi pada suhu $2100^{\circ} \mathrm{C}$ dan akan terurai menjadi pirogallo, pirokatekol, serta floroglusinol [7].

Tanin memiliki rumus molekul $\mathrm{C}_{76} \mathrm{H}_{52} \mathrm{O}_{46}$, berat molekul 1701,22, dapat diidentifikasi menggunakan kromatografi, berwarna kuning atau kecokelatan [8]. Tanin memiliki rasa asam dan sepat, tidak dapat mengkristal dan dapat mengendapkan protein larutannya. Tanin merupakan senyawa kompleks dalam bentuk campuran polifenol yang sukar dipisahkan sehingga sukar mengkristal. Senyawa fenol dari tanin mempunyai aksi astrigensia, antiseptik dan pemberi warna [9].

Tanin mempunyai sifat sebagai agen pengkelat logam karena adanya pengaruh fenolik. Proses pengkhelatan logam dapat terjadi karena adanya kesesuaian pola subtitusi dan $\mathrm{pH}$ senyawa fenolik tersebut, dan dengan demikian tanin akan terhidrolisis. Khelat dari senyawa tanin akan membuat logam dapat stabil dan aman di dalam tubuh. Dengan demikian ada pengaruh tanin di dalam tubuh, jika mengkonsumsi minuman seperti teh secara berlebihan yaitu menyebabkan anemia. Hal ini disebabkan zat besi dalam darah akan di khelat oleh senyawa tanin yang terdapat pada makanan atau minuman tersebut. Tanin dari Solanum trilobatum dapat menghambat pertumbuhan $S$. typhi pada konsentrasi 1,0 dan 2,0 $\mathrm{mg} / \mathrm{ml}[10]$. 


\section{Camellia sinensis}

Camellia sinensis yang dikenal dengan teh berasal dari Cina. Camellia sinensis yang dapat tumbuh pada ketinggian 200-2.300 meter di atas permukaan laut. Tanaman teh memiliki manfaat diantaranya sebagai anti kanker, antioksidan, antimikroba, antibakteria, pencegah aterosklerosis, menjaga kesehatan jantung, antidiabetes, menstimulasi sistem imun, mencegah parkinson, menurunkan kolesterol, mencegah karies gigi, mencegah bau mulut, melancarkan urine, menghindari stroke, dan menurunkan tekanan darah. Hal ini disebabkan kandungan bahan kimia aktif seperti katekin, asam amino, gula, polifenol oksidasi, klorofil dan karoten yang terdapat pada vakuola [11].

C. sinensis menghasilkan metabolit sekunder seperti alkaloid, flavonoid, steroid, tanin, saponin, triterpenoid [12]. Komposisi bahan aktif dalam daun teh lainnya adalah kafein, tanin, theophylline, theobromine, lemak, saponin, minyak esesial, katekin, karoten, vitamin $\mathrm{C}, \mathrm{A}, \mathrm{B}_{1}, \mathrm{~B}_{2}, \mathrm{~B}_{12}, \mathrm{P}$, Fluorite, Ferum, Magnesium, Kalsium, Strontium, Plumbum, Nikel, Zink, dan Phosphor. Kandungan tanin pada daun teh akan semakin meningkat seiring dengan peningkatan usia tanaman [3].

\section{Acalypha indica L}

A. indica memiliki daun tunggal, dengan tepi bergerigi, berbentuk belah ketupat, berwarna hijau, panjang 3-4 cm, lebar $2-3 \mathrm{~cm}$, berujung runcing, terletak menyebar di sepanjang pohon dan batang. Bentuk bunga majemuk berbentuk bulir yang berasal dari ketiak daun dan ujung cabang Tinggi pohon dapat mencapai 1,5 meter, bercabang dengan garis memanjang kasar, berbatang tegak, bulat, berambut halus, berwarna hijau. Buah berbentuk bulat warna hitam, dengan biji berbentuk bulat panjang berwarna coklat dan memiliki akar tunggang Akar tanaman ini sangat disukai hewan anjing dan kucing [13].

A. indica ditemukan di dataran India pada ketinggian $1300 \mathrm{~m}$ dan juga di daerah di luar pegunungan Himalaya. A. indica $L$. memiliki efek anti inflamsi, hepatoprotektif, antifungi, antitusif, antibakteria karena memiliki kandungan tanin, flavonoid, glycosida. Dengan demikian dibutuhkan penelitian lebih lanjut akan potensi tanaman tersebut sebagai tanaman obat [14]. A. indica $L$. ditemukan juga di Indonesia dalam bentik semak (Gambar 1).

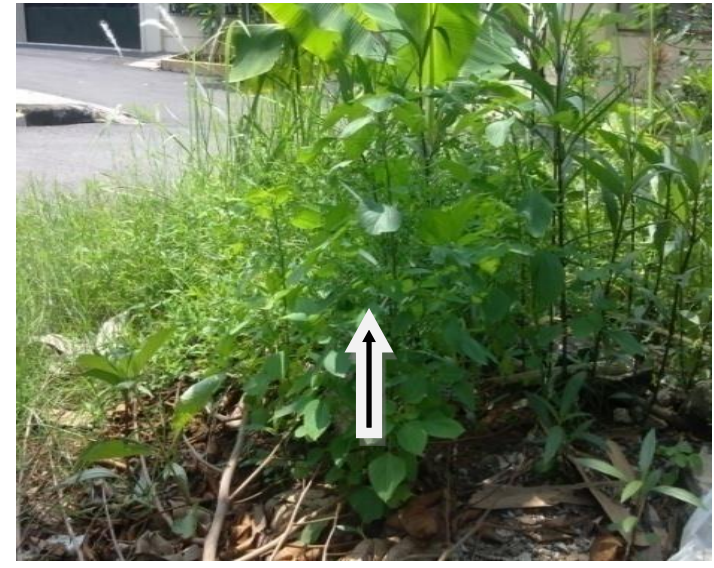

Gambar 1. Tanaman Acalypha indica L

Kandungan kimia dari daun Anting-anting menurut Phytochemical and Enthnobotanical Database antara lain fiber, asam askorbat, beta-sitosterol, beta D-glukosa, tanin, kaempferol. Hasil penelitian menunjukkan etanol yang diperoleh dari ekstrak $A$. indica $L$. dapat memberikan efek pada hepatoprotektif, pengobatan dysfungsi hepar dan antioksida [15].

Tanaman A. indica $L$ memiliki banyak manfaat untuk penyakit pneumonia, asma, rematik, dan macam-macam penyakit kulit. Kandungan heksan, kloroform, etil asetat, dan methanol di dalam $A$. indica dapat dijadikan antibakteria dengan minimum konsentrasi sebesar 0.156-2.5 mg/ml [16]. A. indica $L$ juga dapat digunakan sebagai obat cacing dengan mengekstraksi kandungan alkohol dan dosis terbaik yang diperoleh sebesar $50 \mathrm{mg} / \mathrm{ml}$ [17].

\section{METODOLOGI PENELITIAN}

\section{Lokasi Penelitian}

Penelitian ini dilakukan pada bulan Maret hingga Oktober 2012 di Laboratorium Mikrobiologi Universitas Al Azhar Indonesia.

\footnotetext{
Alat Dan Bahan

Alat-alat yang dibutuhkan dalam penelitian antara lain oven, mortar, alu, beker glass, Erlenmeyer, waterbath, pengaduk, timbangan digital, alumunium, laminar air flow, autoclave, cawan petri, jarum ose, kertas cakram, pemanas dan tabung reaksi. Adapun bahan-bahan yang dibutuhkan adalah daun teh, daun anting-anting, media Nutrien Agar, media Muler Hinton, dan alkohol.
} 


\section{Metode Penelitian}

Pengumpulan daun $C$. sinensis dan $A$. indica $L$. Daun teh didapat dari perkebunan teh di pegunungan daerah desa Pasirlangu Kabupaten Bandung Barat. Pemilihan daun teh berdasarkan dari umur daun teh tersebut. Daun yang digunakan untuk penelitian ini adalah daun tua. Daun antinganting didapat dari daerah Pondok Kelapa Jakarta Timur.

\section{Pembuatan ekstrak daun $C$. sinensis dan $A$. indica}

Metode ekstraksi yang digunakan adalah metode ekstraksi tradisional yang umum dilakukan oleh masyarakat yaitu dengan cara merebus daun $A$. indica sebanyak $100 \mathrm{~g}$ dalam $1000 \mathrm{~mL}$ aquadest hingga terbentuk $500 \mathrm{~mL}$ ekstrak dan selanjutnya dilakukan penyaringan.

Metode ekstraksi lain merujuk pada metode ekstraksi daun teh dan daun anting-anting yaitu dengan mengeringkan daun teh dan daun antinganting pada oven pada suhu $105^{\circ} \mathrm{C}$ sampai mendapatkan berat kering sampel [18].

Daun teh dan daun anting-anting yang sudah kering selanjutnya dihaluskan dengan menggunakan mortar. Sampel yang diperoleh dilarutkan dengan menggunakan aquades perbandingan 1:20 untuk selanjutnya di panaskan dengan menggunakan waterbath atau magnetic strirer pada suhu $100^{\circ} \mathrm{C}$ selama 1 jam. Selanjutnya sampel di uapkan dengan menggunakan oven pada suhu $60^{\circ} \mathrm{C}$.

\section{Penumbuhan $S$. typhi dan pengujian daun anting-anting}

S. typhi ditumbuhkan pada media MüellerHinton dan Nutrien Agar pada cawan petri. Selanjutnya dimasukkan cakram yang telah ditetesi ekstrak daun anting-anting. Inkubasi dilakukan pada suhu $35^{\circ} \mathrm{C}$ selama $24-72$ jam. Efektifan ekstrak daun anting-anting sebagai anti S. typhi. diamati dengan memperhatikan zona bening yang terbentuk di sekitar cakram difusi dan kertas Whatman.

\section{Pengujian tanin dengan $\mathrm{FeCl}_{3}$}

Pengujian kandungan tanin pada daun teh dan anting-anting dilakukan dengan menggunakan larutan $\mathrm{FeCl}_{3}$. Sampel daun kering ditimbang dengan mengunakan timbangan digital sebesar 0,5 $\mathrm{g}$, selanjutnya dilarutkan dengan menggunakan pelarut $50 \mathrm{~mL}$ aquades yang telah dipanaskan sebelumnya.
Larutan tersebut selanjutnya dipanaskan selama 15 menit dan disaring dengan menggunakan kertas saring. Filtrat sebanyak $5 \mathrm{~mL}$ dimaskkan pada tabung reaksi dan direaksikan dengan 2-3 tetes larutan $\mathrm{FeCl}_{3}$ 1\%. Apabila warna sampel berubah menjadi warna hijau kehitaman atau biru tua, maka sampel tersebut mengandung senyawa tanin.

\section{HASIL DAN PEMBAHASAN}

Pengujian efektifitas antibakteria typhi dengan ekstrak A. indica yang dibuat dengan metode tradisional menunjukkan bahwa ekstrak yang dimasukkan pada cakram difusi secara langsung pada hari ke-1 kultur memperlihatkan positif terbentuk zona bening (Gambar 2). Akan tetapi jika peletakan cakram setelah 24 jam kultur dan juga menggunakan kertas Wathmann sebagai tempat ekstrak A. indica, tidak memperlihatkan zona bening (Tabel 1).

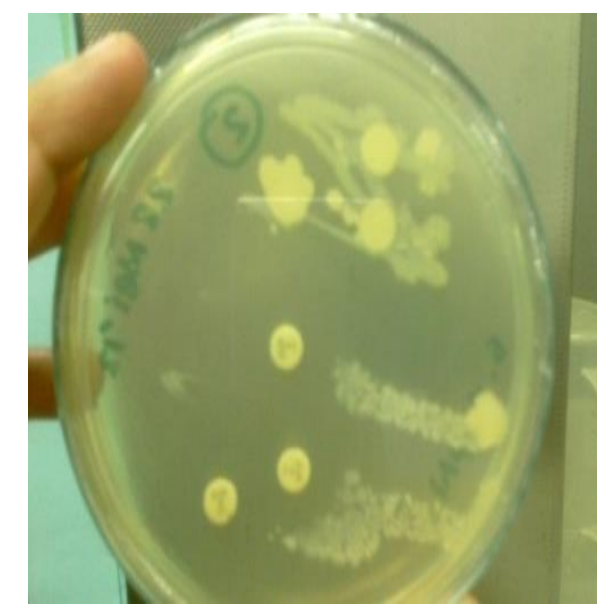

Gambar 2. Zona Bening di sekitar Cakram yang diletakkan Bersamaan kultur S.thypi (pengamatan hari ke-2)

Tabel 1. Pengujian Efektifitas Antibakteria Ekstrak A. indica $L$. dengan Metode Tradisional (Perebusan)

\begin{tabular}{|l|c|c|}
\hline Perlakuan & $\begin{array}{c}\text { Peletakan } \\
\text { Langsung }\end{array}$ & $\begin{array}{c}\text { Peletakan } \\
\text { setelah 24 jam }\end{array}$ \\
\hline Cakram & $(+)$ & $(-)$ \\
\hline Whatman & $(-)$ & $(-)$ \\
\hline
\end{tabular}

(+) Zona bening terbentuk

(-) Zona bening tidak terbentuk

Keterangan : A1 : perlakuan pertama A2 : perlakuan kedua 
Penghambatan kemampuan antibakteri disebabkan kecepatan pertumbuhan bakteri yang tinggi. Selain itu cakram memiliki kemampuan untuk mengikat ekstrak tanin yang lebih tinggi dibandingkan kertas Wathman [19].

Hal yang berbeda dengan metode ekstraksi pengeringan. Pengujian efektifitas antibakteri dengan $A$. indica melalui ekstraksi pengeringan menunjukkan negatif (Tabel 2), hasil ini berbeda dengan metode tradisional (perebusan).

Keadaan ini kemungkinan disebabkan adanya zat bioaktif mengalami pada waktu pengeringan. Zat bioaktif tersebut diduga termasuk zat antibakteria. Zat antibakteria pada ekstrak daun anting-anting kemungkinan adalah tanin. Tanin berperan sebagai antibakteria karena memiliki kemampuan mengubah protein bakteri menjadi senyawa kompleks melalui ikatan hidrogen [20].

Tabel 2 .Data zona penghambat ekstrak A. indica dengan cakram difusi (Medium Muller Hinton)

\begin{tabular}{cc}
\hline Perlakuan & Zona Hambat \\
\hline A1 & $(-)$ \\
B1 & $(-)$ \\
A2 & $(-)$ \\
B2 & $(-)$ \\
C1 & $(-)$ \\
C2 & $(-)$ \\
\hline
\end{tabular}

Keterangan: A1, B1, C1 adalah cakram difusi pada petridish 1, A2, B2, C2 Kertas Whatman pada petridish 2.

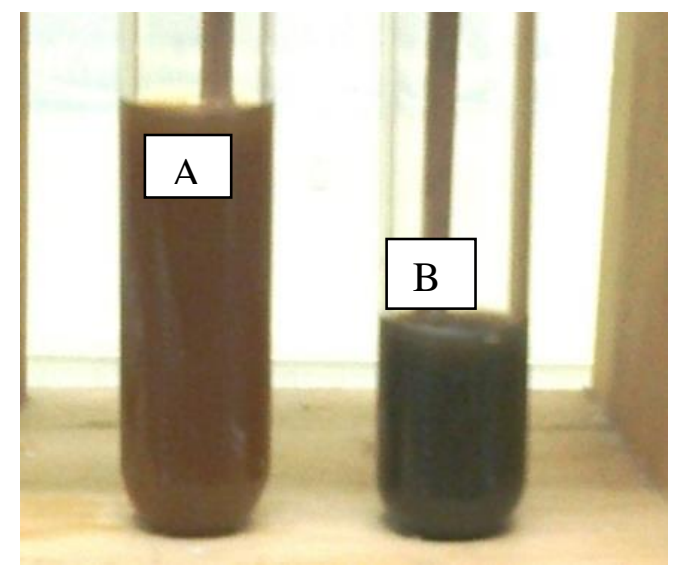

Gambar 3. A. Warna sebelum pengujian tannin; B.Positif mengandung tanin (warna hijau kehitaman)
Tanin menghambat pertumbuhan bakteri dengan mereaksikan protein pada membrane sel, menginaktivasi enzim dan juga destruksi fungsi dan juga materia genetik. Untuk memastikan tanin pada ekstrak daun $A$. indica dan $C$. sinensis $L$ dilakukan pengujian.

Hasil pengujian pada ekstrak $C$. sinensis menunjukkan positif berwarna hijau kehitaman (Gambar 3) dengan demikian jenis tanin yang diperoleh adalah tanin galat. Hal ini disebabkan karena adanya reaksi dengan Natrium asetat dan $\mathrm{FeCl}_{3} 1 \%$. Demikian juga halnya pada pengujian tanin pada $A$. indica $L$. memperlihatkan positif (Tabel 3).

Tanin menyebabkan terganggunya stabilitas dinding sel bakteri yang selanjutnya merunkan fungsi selektif permeabilitas dari membran. Tanin juga dapat menurunkan sistem transport aktif dan terganggunya susunan sel bakteri. Reaksi tanin lain adalah mampu mengikat peptidoglikan membran bakteri. Tanin mempunyai daya antibakteri karena menginterfensi dinding sel bakteri [21].

Tabel 3. Hasil Pengujian Tanin

\begin{tabular}{cccc}
\hline \multirow{2}{*}{ SAMPEL } & \multicolumn{3}{c}{ TANIN } \\
\cline { 2 - 4 } & \multicolumn{3}{c}{ Ulangan: } \\
\cline { 2 - 4 } & I & II & III \\
\hline Camellia sinensis & $(+)$ & $(+)$ & $(+)$ \\
Acalypha indica L & $(+)$ & $(+)$ & $(+)$ \\
\hline
\end{tabular}

Tabel 4. Pengujian efektifitas antibakteri $C$. sinensis Setelah 24 jam dengan metode Cakram (Medium Muller Hinton)

\begin{tabular}{cc}
\hline CAKRAM & ZONA BENING $(\mathrm{mm})$ \\
\hline A1 & 19 \\
A2 & 21 \\
B1 & 21 \\
B2 & 22 \\
C1 & 20 \\
C2 & 24 \\
\hline
\end{tabular}

Keterangan : 1, 2 adalah ulangan

Efektifitas antibakteri dari $C$. sinensis ditunjukkan pada Tabel 4. Daya hambat pertumbuhan bakteri memiliki kemampuan yang mengimbangi antibiotik Chloramfenicol 30 microgram. Diameter zona bening yang terbentuk untuk merekomendasikan 


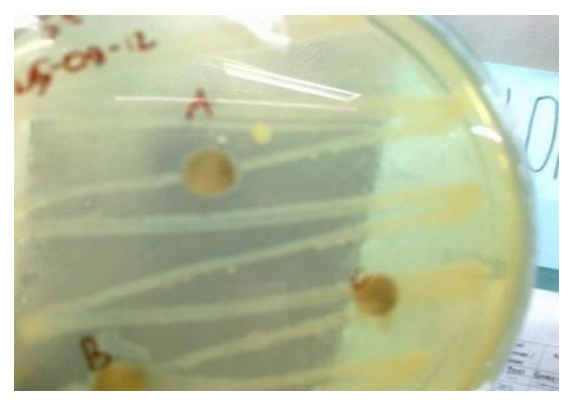

Gambar 4. Zona bening disekitar cakram ekstrak daun teh (Setelah 24 Jam, medium NA)

suatu zat menjadi antibiotika adalah lebih dari 18 $\mathrm{mm}$ [22]. Pada penelitian ini diameter zona bening rata-rata yang dapat terbentuk adalah $21,66 \mathrm{~mm}$.

Terdapat perbedaan efek ekstrak $C$. sinensis yang diletakkan pada cakram difusi dan kertas Wathman baik pada kultur tuang $S$. thypi maupun kultur gores (Gambar 4) dan (Tabel 5).

Pada kultur gores peletakan kertas Wathman A yang berisi $C$. sinensis dilakukan pada hari kedua kultur. Pada metode ini zona bening hanya terdapat pada satu kertas Wathman (A), dan tidak terjadi pada kertas Whatman yang lain. Fenomena ini dapat disebabkan oleh konsentrasi ekstrak C.sinensis yang tidak sama pada ke-3 kertas Wathman tersebut.

Pada hari ke-1 S. typhi belum mengalami pertumbuhan, sehingga ekstrak daun teh dapat melumpuhkan bakteri. Dengan demikian ekstrak $C$. sinensis berpotensi sebagai antibakteria S. typhi.

Berdasarkan zona bening yang terbentuk di sekitar ekstrak $C$. sinensis pada cakram difusi dan kertas Whatman yang diletakkan pada hari ke-1 kultur $S$. thyphi yang dilakukan cara penuangan memperlihatkan lebih efektif.

Hal ini ditunjukkan dengan diameter zona bening metode tuang yang lebih luas dibandingkan gores (Gambar 5 dan 6).

Tabel 5. Diameter zona bening ekstrak $C$. sinensis setelah 24 jam dengan Metode Kertas Whatman

\begin{tabular}{cc}
\hline Perlakuan & Zona Hambat $(\mathrm{mm})$ \\
\hline A1 & 10 \\
B1 & 0 \\
C1 & 0 \\
\hline
\end{tabular}

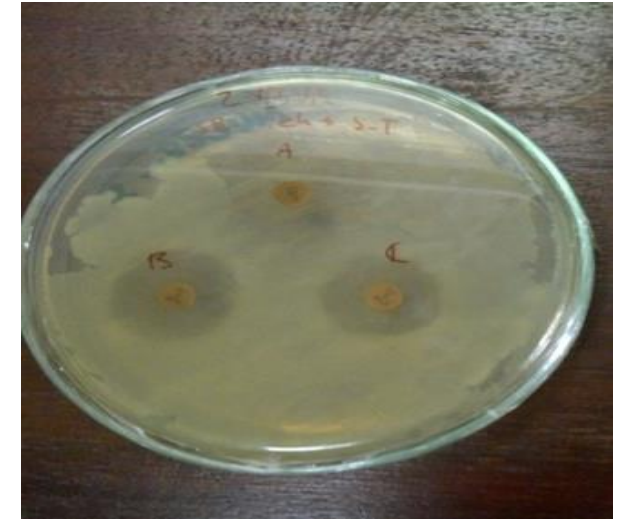

Gambar 5. Zona bening di sekitar cakram difusi ekstrak daun $C$. sinensis (setelah 24 Jam)

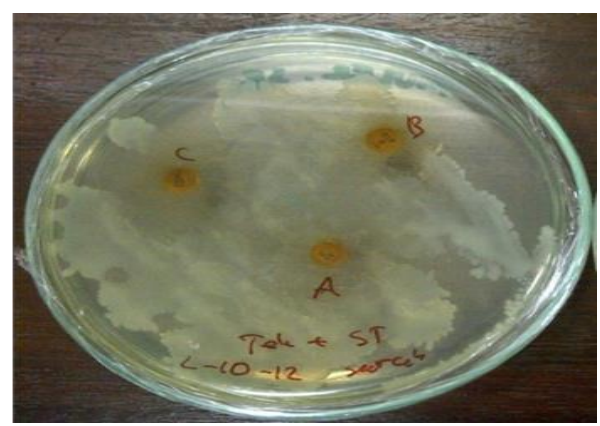

Gambar 6. Zona Bening di sekitar kertas Whatman yang berisi ekstrak $C$. sinensis (setelah 24 jam)

\section{KESIMPULAN}

Ekstrak $C$. sinensis yang diperoleh melalui metode pengeringan berpotensi sebagai antibakteria terhadap S. thypi. Berbeda dengan ekstrak Acalypha indica $L$, potensi sebagai anti Salmonella thypi diperoleh melalui metode ekstraksi perebusan. Zat bioaktif yang terdapat pada kedua tanaman tersebut dan mampu menghambat pertumbuhan $S$. thypi adalah tanin.

\section{UCAPAN TERIMA KASIH}

Ucapan terima kasih penulis sampaikan kepada Lembaga Penelitian dan Pengabdian Masyarakat (LP2M) Universitas Al Azhar Indonesia yang telah memberikan hibah untuk mendanai penelitian ini. Ucapan Terima kasih juga disampaikan kepada Laboratorium Mikrobiologi Universitas Al Azhar Indonesia yang telah menyediakan fasilitas untuk melakukan penelitian. 


\section{DAFTAR PUSTAKA}

[1] AC. John, PL. Stephen, DM. Eric. The global burden of typhoid fever. Bull World Health Organ. 82(5): 346-353. 2004.

[2] Rasmilah Thypus. http://repository.usu.ac.id/bitstream/123456789/374 5/1/fkmrasmaliah5.pdf, 2001. (Diakses pada 1 Oktober 2012).

[3] S. Fulder. Khasiat teh hijau. Prestasi Pustaka. Jakarta. 2004.

[4] H.P.S. Makkar, K. Becker. Do tannins in leaves of trees and shrubs from Africa and Himalayan regions differ in level and activity? Agroforestry Syst. 40. 59-68, 1998.

[5] Danarto YC, Prihananto SA, Pamungkas ZA. Pemanfaatan Tanin dari kulit Kayu Tembakau sebagai Pengganti Gugus Fenol pada Resin Fenol Formaldehid. Universitas Negeri Solo. 2011.

[6] M. Jawetz, Adelberg's. Mikrobiologi Kedokteran. edisi 23. Alih Bahasa: Huriwati Hartanto dkk. Jakarta, Penerbit Buku Kedokteran ECG. 2005.

[7] J. Song, X. Gao, JE. Galan, Structure and function of the Salmonella Typhi chimaeric A2B5 typhoid toxin. Nature. 499: 350-354. 2013.

[8] T. Humphrey, "Salmonella, Stress Responses and Food Safety". Nature Reviews Micriobiology. 2: 504- 509. 2004.

[9] SP. Faucher, Porwollik, Steffen, Dozois, Charles, McClelland, Michael, Daigle, France. "Transcriptome of Salmonella enterica serovar Typhi within macrophages revealed through the selective capture of transcribed sequences". The National Academy of Sciences of the USA. 103:1906-1911. 2006.

[10] A.H. Doss, M. Mubarack, Dhanabalan. Antibacterial activity of tannins from the leaves of Solanum tribolatum Linn. Indian Journal of Science and Technology (2)2. Feb 2009.

[11] N. A. Alamsyah, Taklukkan penyakit dengan the hijau, Penerbit Agrimedia Pustaka, Jakarta. 2006.

[12] S. Lenny, Senyawa Terpenoida dan Steroida. Karya Ilmiah Fakultas MIPA, Universitas Sumatera Utara, Medan. 2006.
[13] R. Octarini, Pengaruh ekstrak herba anting-anting (Acalypha australis L.) terhadap kadar glukosa darah mencit Balb/C induksi Streptozotocin. Skripsi. Universitas Sebelas Maret Surakarta. 2010.

[14] D. Jagatheeswari, J. Deepa, HSJ. Ali, Ranganathan P. Acalypha indica L. an Important Medicinal Plant: a Review of Its Traditional Uses and Pharmacological Properties. International Journal of Research in Botany. 3(1): 19-22. 2013.

[15] M. Mathew, C. Nair, T. Shenoy, J. Varghese, Preventive and curative effects of Acalypha indica on acetaminophen-induced hepatotoxicity. Int $\mathbf{J}$ Green Pharm 2011;5:49-54.

[16] M. Govindarajan, A. Jebanesan, D. Reetha, R. Amsath, T. Pushpanathan, K. Samidurai, Antibacterial activity of Acalypha indica L. J. European review for medical and pharmacological sciences. 12: 299-302. 2008.

[17] B. Chengaiah, KM. Kumar, M. Alagusundaram, C. Sasikala, CM. Chetty, In vitro anthelmintic activity of root of Acalypha indica Linn. International journal of pharmtech research. 1 (4): 1499-1502. 2009.

[18] Subiyakto. Pemanfaatkan langsung serbuk kulit kayu akasia sebagai perekat papan partikel. Jurnal ilmu dan teknologi kayu lapis vol 1. 2003.

[19] T. Nirbita, Uji Aktivitas Antioksidan dan Antibakteri (Escherichia coli dan Stahaphylococcus aureus) Kunyit putih dan Produk Olahannya (Bubuk Effervescent Kunyit Putih). Skripsi. Fakultas Teknologi Pertanian Universitas Brawijaya, Malang. 2002.

[20] W. Safera, Optimasi Waktu Ekstraksi Terhadap Kandungan Tanin pada Bubuk Ekstrak Daum Biji serta Analisis Finansialnya. Jurusan Teknologi Pertanian, Fakultas Teknologi Pertanian, Universitas Brawijaya Malang. 2005.

[21] P. Erasto, G. Bijase-Moleta, RRT. Majinda, Antimicrobial and antioxidanat flavonoid from the roots wood of Bolusthus spesiosus. Phytochem. 65, 875-880. 2004.

[22] G. Meyer, Antibiotics Protein Synthesis, Nucleic Acid Synthesis and Metabolisme. Mycrobiology and Imunology Online. University of South Carollina School of Medicine. 2012. 